\title{
Prediksi Besaran Curah Hujan Menggunakan Metode Fuzzy Time Series
}

\author{
Diera Desmonda $^{\# 1}$, Tursina ${ }^{\# 2}$, M Azhar Irwansyah $^{\# 3}$ \\ \#Program Studi Informatika Universitas Tanjungpura \\ Jl. Prof. Dr. H. Hadari Nawawi, Pontianak, Kalimantan Barat 78115 \\ ${ }^{1}$ diera.desmonda@gmail.com, \\ ${ }^{2}$ tursinaeinformatika.untan.ac.id, \\ ${ }^{3}$ irwansyah.azharegmail.com
}

\begin{abstract}
Abstrak - Iklim tropis yang memiliki dua musim, yakni musim penghujan dan musim kemarau yang seharusnya berputar setiap enam bulan sekali. Namun beberapa tahun terakhir ini, perubahan iklim global terasa ditandai dengan tidak menentunya perputaran musim kemarau maupun musim penghujan. Untuk mengetahui perubahan pola curah hujan tersebut, maka dirancanglah prediksi besaran curah hujan untuk melihat dan menganalisa pola hujan yang akan terbentuk ke depannya. Aplikasi prediksi besaran curah hujan yang akan dibangun menggunakan forecasting atau peramalan dengan metode Fuzzy Time Series. ${ }^{[1]}$ Logika fuzzy digunakan karena dapat memetakan suatu input ke dalam suatu output dan memiliki toleransi terhadap data-data yang tersedia. ${ }^{[2]}$ Adapun hasil dari penelitian yang dilakukan adalah mengimplementasikan metode Fuzzy Time Series untuk membangun aplikasi yang dapat mengolah dan menentukan pola data curah hujan serta memprediksi besaran curah hujan. Hasil dari pengujian diperoleh nilai MAPE (Mean Average Percentage Error) bervariasi tergantung jumlah data dan jumlah interval yang digunakan. Nilai $M A P E$ terbaik yang diperoleh adalah 0,151\% pada penggunaan data curah hujan periode 2015 - 2017 dengan jumlah interval 401. Perhitungan menggunakan metode Fuzzy Time Series sangat dipengaruhi oleh jumlah data yang digunakan dan jumlah interval dalam membagi data tersebut.
\end{abstract}

Kata Kunci : curah hujan, forecasting, Fuzzy Time Series, logika fuzzy, time series)

\section{PENDAHULUAN}

Pontianak, ibukota Provinsi Kalimantan Barat, dikenal sebagai kota khatulistiwa karena tepat dilalui oleh garis lintang nol derajat atau garis khatulistiwa (equator). Sebagai kota yang terletak pada garis lintang nol derajat, Pontianak termasuk dalam negara yang berada dalam wilayah iklim tropis dan memiliki dua musim yaitu musim kemarau dan musim penghujan. ${ }^{[3]}$

Musim penghujan adalah musim dengan ciri meningkatnya curah hujan di suatu wilayah dibandingkan biasanya dalam jangka waktu tertentu secara tetap. ${ }^{[4}$ Sedangkan curah hujan adalah banyaknya hujan yang tercurah (turun) di suatu daerah dalam jangka waktu tertentu. Musim kemarau dan musim penghujan berganti selama enam bulan sekali. Namun menurut WWF (World Wildlife Fund for Nature) Indonesia, beberapa tahun terakhir ini, perubahan iklim global terasa ditandai dengan tidak menentunya perputaran musim kemarau maupun musim penghujan. Untuk mengetahui perubahan pola curah hujan tersebut, maka dirancanglah prediksi besaran curah hujan untuk melihat dan menganalisa pola hujan yang akan terbentuk ke depannya.

Prediksi atau forecasting adalah meramalkan, memproyeksikan, atau mengadakan perkiraan / taksiran terhadap berbagai kemungkinan yang akan terjadi pada masa mendatang. ${ }^{[5]}$ Prediksi atau forecasting dapat dilakukan dengan melibatkan pengambilan data historis dan memproyeksikannya ke masa mendatang dengan suatu bentuk model matematis. ${ }^{[6]}$ Metode peramalan (forecasting) terdiri dari metode kualitatif dan kuantitatif. Salah satu metode yang termasuk metode kuantitatif adalah metode time series atau runtun waktu. ${ }^{[7]}$ Time series atau runtun waktu adalah himpunan observasi data terurut dalam waktu, ${ }^{[8]}$ sehingga metode time series menganalisis dan menentukan pola data pada masa lampau yang dikumpulkan berdasarkan urutan waktu dan memproyeksikannya untuk mendapatkan prediksi di masa mendatang. ${ }^{[9]}$ 


\section{URAIAN PENELITIAN}

\section{A. Teori Hujan}

Curah hujan merupakan ketinggian air hujan yang terkumpul dalam tempat yang datar, tidak menguap, tidak meresap, dan tidak mengalir. Satuan curah hujan selalu dinyatakan dalam satuan milimeter atau inchi namun untuk di Indonesia satuan curah hujan yang digunakan adalah dalam satuan milimeter (mm). Curah hujan dalam 1 (satu) milimeter memiliki arti dalam luasan satu meter persegi pada tempat yang datar tertampung air setinggi satu milimeter atau tertampung air sebanyak satu liter. ${ }^{[10]}$ Pengukuran dapat dilakukan secara langsung dengan menampung air hujan yang jatuh, namun tidak dapat dilakukan di seluruh wilayah tangkapan air, akan tetapi hanya dapat dilakukan pada titiktitik yang ditetapkan dengan menggunakan alat pengukur hujan. ${ }^{[11]}$

\section{B. Data Time Series}

Data Time Series atau data berkala adalah data yang dikumpulkan dari waktu ke waktu, untuk menggambarkan perkembangan suatu kegiatan. ${ }^{[12]}$ Analisis data berkala memungkinkan kita untuk mengetahui perkembangan suatu atau beberapa kejadian serta hubungan/pengaruhnya terhadap kejadian lainnya. ${ }^{[13]}$ Pola gerakan data atau nilai-nilai variabel dapat diikuti atau diketahui dengan adanya data berkala, sehingga data berkala dapat dijadikan sebagai dasar untuk pembuatan keputusan, peramalan keadaan perdagangan dan ekonomi pada masa yang akan dating, serta perencanaan kegiatan dimasa yang akan datang. ${ }^{[14]}$

\section{Logika Fuzzy}

Secara umum logika fuzzy adalah suatu logika yang memiliki nilai kekaburan atau kesamaran (fuzzyness) antara benar atau salah. Logika Fuzzy memungkinkan nilai keanggotaannya antara 0 dan $1 .^{[15]}$ Logika fuzzy adalah suatu cara yang tepat untuk memetakan suatu ruang input ke dalam suatu ruang output, mempunyai nilai kontinyu dan logika fuzzy dinyatakan dalam derajat dari suatu keanggotaan dan derajat dari kebenaran. ${ }^{[16]}$

\section{Peramalan dengan Metode Fuzzy Time Series}

Perbedaan utama antara fuzzy time series dan konvensional time series yaitu pada nilai yang digunakan dalam peramalan, yang merupakan himpunan fuzzy dari bilangan-bilangan real atas himpunan semesta yang ditentukan. ${ }^{[17]}$ Himpunan fuzzy dapat diartikan sebagai suatu kelas bilangan dengan batasan yang samar. ${ }^{[18]}$

\section{Universe of Discource}

Menentukan batas semesta pembicaraan atau Universe of Discourse dengan cara menentukan data terkecil dan data terbesar dari data time series sehingga terbentuk Universe of Discourse sebagai [Dmin, Dmax]. Maka sesuai Tabel I, Universe of Discourse yang digunakan adalah [13.60, 39.73].
TABEL I

TABEL DATA TIME SERIES

\begin{tabular}{|l|l|l|r|l|l|}
\hline Waktu & Data & Waktu & \multicolumn{1}{|c|}{ Data } & Waktu & Data \\
\hline Jan-15 & 19.19 & Jan-16 & 29.41 & Jan-17 & 19.82 \\
\hline Feb-15 & 24.10 & Feb-16 & 22.76 & Feb-17 & 39.73 \\
\hline Mar-15 & 22.00 & Mar-16 & 26.69 & Mar-17 & 23.18 \\
\hline Apr-15 & 21.00 & Apr-16 & 21.39 & Apr-17 & 24.38 \\
\hline Mei-15 & 24.51 & Mei-16 & 21.38 & Mei-17 & 23.45 \\
\hline Jun-15 & 25.82 & Jun-16 & 20.75 & Jun-17 & 21.84 \\
\hline Jul-15 & 32.93 & Jul-16 & 28.47 & Jul-17 & 31.48 \\
\hline Agu-15 & 13.60 & Agu-16 & 17.75 & Agu-17 & 27.97 \\
\hline Sep-15 & 14.20 & Sep-16 & 18.97 & Sep-17 & 23.07 \\
\hline Okt-15 & 22.95 & Okt-16 & 22.44 & Okt-17 & 15.31 \\
\hline Nov-15 & 23.22 & Nov-16 & 24.73 & Nov-17 & 18.38 \\
\hline Des-15 & 24.34 & Des-16 & 25.27 & Des-17 & 15.89 \\
\hline
\end{tabular}

2. Perhitungan Interval Berbasis Rata-rata

Menentukan interval berbasis rata-rata dengan cara menghitung setengah dari hasil rata-rata nilai selisih antar data time series kemudian dibulatkan berdasarkan Tabel I. Nilai interval diperoleh dengan membagi jangkauan dengan nilai perhitungan yang telah dibulatkan berdasarkan Tabel I. ${ }^{[19]}$

TABEL II

TABEL BASIS INTERVAL

\begin{tabular}{|c|c|}
\hline Jangkauan & Basis \\
\hline $0.1-1.0$ & 0.1 \\
\hline $1.1-10$ & 1 \\
\hline $11-100$ & 10 \\
\hline $101-1000$ & 100 \\
\hline
\end{tabular}

Dari 36 data yang digunakan, diperoleh nilai rata-rata selisihnya sebesar 4.987. Kemudian nilai 4.987 dibagi dua diperole nilai 2.494 yang dirujuk pada Tabel II maka basis interval yang digunakan adalah 1. Nilai 2.494 dibulatkan menjadi 2 sebagai panjang interval efektif. Jumlah interval diperoleh dari jangkauan dibagi dengan panjang interval. Jangkauan diperoleh dari Dmax - Dmin yakni 39.73 - 13.60 diperoleh nilai 26.13 yang kemudian dibagi dengan panjang interval 2 maka diperoleh nilai 13.067 yang dibulatkan menjadi 13 sebagai jumlah interval efektif.

\section{Himpunan Fuzzy}

Menentukan himpunan dengan cara membagi jangkauan dengan sejumlah interval kemudian menentukan nilai linguistik dari masing-masing himpunan yang terbentuk menjadi sejumlah himpunan fuzzy.

\section{Fuzzifikasi}

Menentukan nilai fuzzifikasi dari masing-masing himpunan fuzzy yang telah terbentuk menjadi Ai dengan i sebanyak jumlah himpunan fuzzy. 
TABEL III

TABEL FUZZIFIKASI DATA

\begin{tabular}{|l|r|l|}
\hline Waktu & \multicolumn{1}{|c|}{ Data } & Hasil Fuzzifikasi \\
\hline Jan-15 & 19.19 & A4 \\
\hline Feb-15 & 24.1 & A6 \\
\hline Mar-15 & 22 & A5 \\
\hline$\ldots$ & $\ldots$ & $\ldots$ \\
\hline Okt-17 & 15.31 & A2 \\
\hline Nov-17 & 18.38 & A3 \\
\hline Des-17 & 15.89 & A2 \\
\hline
\end{tabular}

5. Fuzzy Logic Relationship (FLR)

Menentukan Fuzzy Logic Relationship (FLR) dengan menghubungkan nilai fuzzifikasi dari data $\mathrm{D}(\mathrm{t}) \rightarrow \mathrm{D}(\mathrm{t}-1)$ sehingga terbentuk Fuzzy Logic Relationship dari masingmasing data time series yang dihubungkan ke data time series sesudahnya.

TABEL IV

TABEL FUZZY LOGIC RELATIONSHIP (FLR)

\begin{tabular}{|l|l|}
\hline Waktu & Hasil Fuzzifikasi \\
\hline Jan-15 $\rightarrow$ Feb-15 & A4 $\rightarrow$ A6 \\
\hline Feb-15 $\rightarrow$ Mar-15 & A6 $\rightarrow$ A5 \\
\hline Mar-15 $\rightarrow$ Apr-15 & A5 $\rightarrow$ A4 \\
\hline$\ldots$ & $\ldots$ \\
\hline Okt-17 $\rightarrow$ Nov-17 & A2 $\rightarrow$ A4 \\
\hline Nov-17 $\rightarrow$ Des-17 & A3 $\rightarrow$ A2 \\
\hline Des-17 $\rightarrow$ Jan-18 & --- \\
\hline
\end{tabular}

\section{Fuzzy Logic Relationship Group (FLRG)}

Menentukan Fuzzy Logic Relationship Group (FLRG) dengan mengelompokkan semua FLR yang memiliki current_state yang sama sehingga terbentuk serangkaian pola untuk melakukan proses perhitungan.

TABEL V

TABEL FUZZY LOGIC RELATIONSHIP GROUP (FLRG)

\begin{tabular}{|l|l|l|l|}
\hline $\begin{array}{l}\text { Current_ } \\
\text { state }\end{array}$ & $\begin{array}{l}\text { Next__ } \\
\text { state }\end{array}$ & $\begin{array}{l}\text { Current_- } \\
\text { state }\end{array}$ & $\begin{array}{l}\text { Next_- } \\
\text { state }\end{array}$ \\
\hline $\mathrm{A} 1 \rightarrow$ & A1, A5 & A8 $\rightarrow$ & A3, A5 \\
\hline A2 $\rightarrow$ & A3 & A9 $\rightarrow$ & A8 \\
\hline A3 $\rightarrow$ & A2, A3, A5 & A10 $\rightarrow$ & A1 \\
\hline A4 $\rightarrow$ & A6, A8, A13 & A11 $\rightarrow$ & - \\
\hline A5 $\rightarrow$ & $\begin{array}{l}\text { A2, A4, A5, A6, A7, } \\
\text { A9 }\end{array}$ & A12 $\rightarrow$ & - \\
\hline A6 $\rightarrow$ & A4, A5, A6, A7, A8 & A13 $\rightarrow$ & A5 \\
\hline A7 $\rightarrow$ & A5, A10 & & \\
\hline
\end{tabular}

\section{Defuzzifikasi}

Menentukan nilai defuzzifikasi dari masing-masing FLRG yang terbentuk dengan merata-ratakan nilai linguistik himpunan fuzzy yang terkelompokkan dalam FLRG tersebut.
Sebagai contoh, himpunan A1 memiliki next_state A1 dan A5, sehingga defuzzifikasinya diperoleh dengan $\frac{A 1+A 5}{2}=\frac{13.60+22.92}{2}=\frac{35.92}{2}=17.96$.

\section{PERANCANGAN APLIKASI}

A. Arsitektur Sistem

Desain arsitektur sistem ditunjukkan pada Gambar 1.

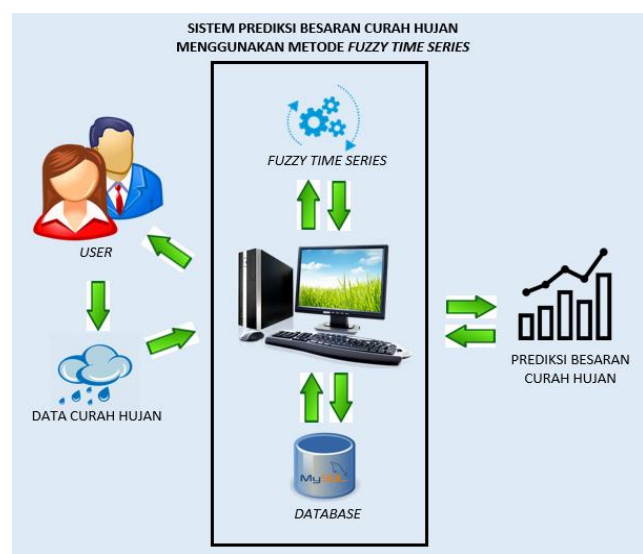

Gambar 1. Arsitektur Sistem

User memasukkan data curah hujan ke dalam sistem. Data tersebut selanjutnya akan disimpan ke dalam database. Sistem akan menentukan pola data curah hujan menggunakan perhitungan Fuzzy Time Series. Pola data curah hujan yang diperoleh melalui perhitungan Fuzzy Time Series akan diproyeksikan untuk memprediksi besaran curah hujan pada periode mendatang.

B. Antarmuka Aplikasi

Struktur antarmuka aplikasi ditunjukkan pada Gambar 2.

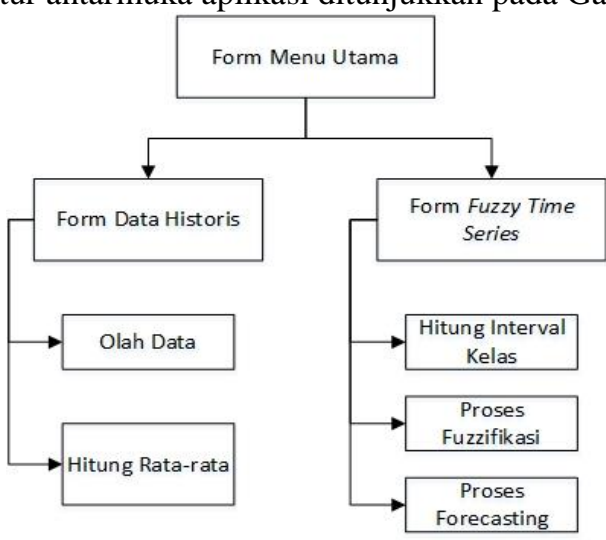

Gambar 2. Struktur Antarmuka Aplikasi

Aplikasi yang dirancang memiliki tiga form utama yakni Form Menu Utama, Form Data Historis, dan Form Fuzzy Time Series. Pada Form Menu Utama halaman yang ditampilkan paling pertama setelah user membuka atau menjalankan aplikasi. Pada halaman utama terdapat tombol menu untuk mengakses proses olah data dan perhitungan Fuzzy Time Series. 
Form Data Historis memiliki 2 panel terpisah yakni, panel Olah Data dan panel Hitung Rata-rata. Panel Olah Data berfungsi untuk menginput, mengubah, dan menghapus data, sedangkan Panel Hitung Rata-rata berfungsi untuk menghitung rata-rata data per-bulan serta menyimpannya ke dalam basis data.

Form Fuzzy Time Series memiliki 3 panel terpisah yakni, Panel Interval, Panel Fuzzy Time Series, serta Panel Forecasting. Panel Interval berfungsi untuk menghitung interval rata-rata yang akan menjadi acuan interval ideal yang dapat digunakan pada proses perhitungan Fuzzy Time Series pada tahap berikutnya. Panel Fuzzy Time Series berfungsi untuk menghitung data-data secara bertahap sesuai dengan metode Fuzzy Time Series. Panel Forecasting berfungsi untuk melakukan proses forecasting atau peramalan berdasarkan hasil perhitungan Fuzzy Time Series pada tahap sebelumnya.

\section{Pengujian Aplikasi}

Pengujian aplikasi menggunakan metode perhitungan Mean Average Percentage Error (MAPE). MAPE dihitung dengan menggunakan kesalahan absolut pada tiap periode dibagi dengan nilai observasi yang nyata untuk periode itu dan kemudian nilai tersebut dirata-ratakan. ${ }^{[20]} M A P E$ mengindikasikan seberapa besar kesalahan dalam meramal yang dibandingkan dengan nilai nyata. MAPE diperoleh dengan menggunakan Persamaan 1.

$$
\text { MAPE }=\frac{100 \%}{n} \sum_{t=1}^{n}\left|\frac{X_{t}-\widehat{X_{t}}}{X_{t}}\right|
$$

dengan

$$
\begin{array}{ll}
n & =\text { banyak data } \\
X_{\mathrm{t}} & =\text { data observasi nyata pada waktu } \mathrm{t} \\
\overline{X_{t}} & =\text { data hasil peramalan pada waktu } \mathrm{t}
\end{array}
$$

\section{HASIL PERANCANGAN DAN ANALISIS}

\subsection{Hasil Uji Aplikasi}

Dalam pengujian oleh program digunakan data time series dalam 15 periode waktu yang berbeda, yaitu dari 1 tahun, 2 tahun, 3 tahun, hingga 15 tahun. Masing-masing data yang digunakan terdiri dari data aktual 12 bulan dari Januari hingga Desember setiap tahun pada setiap periode, sehingga terdapat 12 data pada periode 1 tahun, 24 data pada periode 2 tahun, 36 data pada periode 3 tahun, hingga 180 data pada periode 15 tahun. Pada pengujian masing-masing periode digunakan berbagai interval hingga ditemukan nilai interval optimal yakni interval 401 yang menghasilkan nilai $M A P E$ terbaik dari semua hasil pengujian. Pengujian-pengujian dengan menggunakan jumlah interval berbeda akan menghasilkan nilai $M A P E$ yang berbeda yang pula, namun untuk mengoptimalkan hasil perbandingan antardata, maka digunakanlah jumlah interval yang sama yakni 401.

Hasil pengujian terbaik terdapat pada pengujian dengan jumlah tahun sebanyak 3 tahun dengan periode pengujian tahun 2015 - 2017 dengan menggunakan interval optimal 401.
Nilai MAPE pada pengujian tersebut adalah sebesar $0.1509 \%$, sehingga diperoleh nilai akurasi atau ketepatan sebesar 99.8491\%. Sedangkan pengujian dengan hasil MAPE terbaik adalah $0.6460 \%$ yaitu pada pengujian 4 tahun periode 2014 2017 dengan nilai akurasi atau ketepatan sebesar $99.354 \%$. Hasil pengujian dengan nilai MAPE terbesar adalah $7.6522 \%$ yaitu pada pengujian 15 tahun periode 2003 - 2017 dengan nilai akurasi atau ketepatan sebesar 92.3478\%. Beberapa gambar grafik perbandingan nilai data aktual dengan hasil prediksi dapat dilihat pada Gambar 3, Gambar 4, dan Gambar 5 .

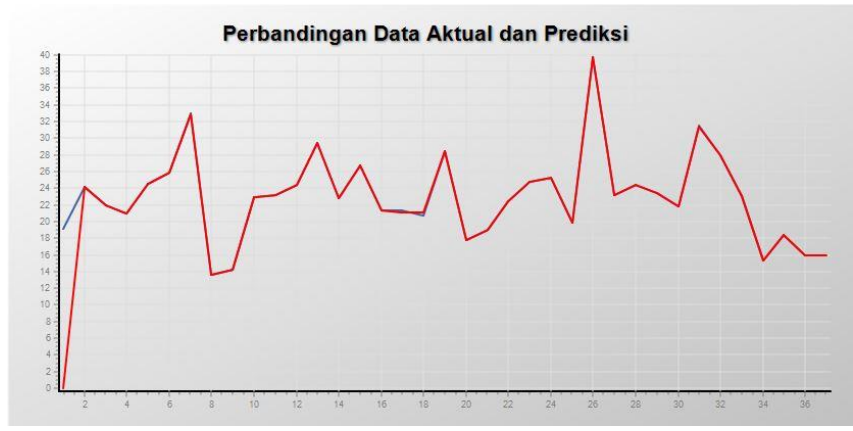

Gambar 3. Struktur Antarmuka Aplikasi

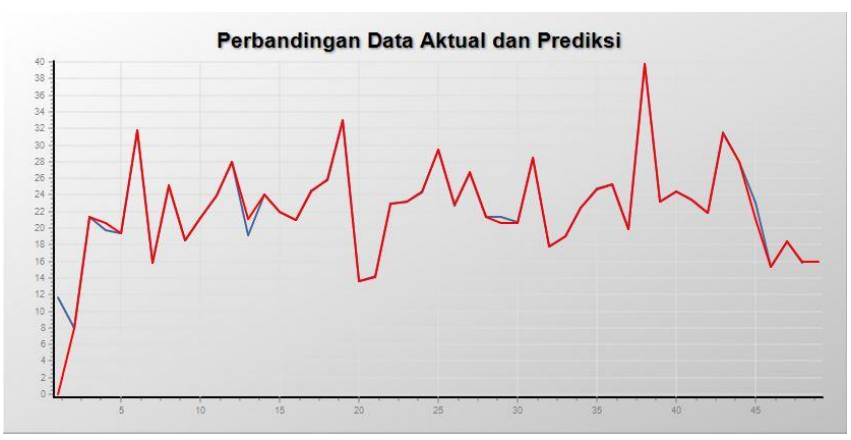

Gambar 4. Struktur Antarmuka Aplikasi

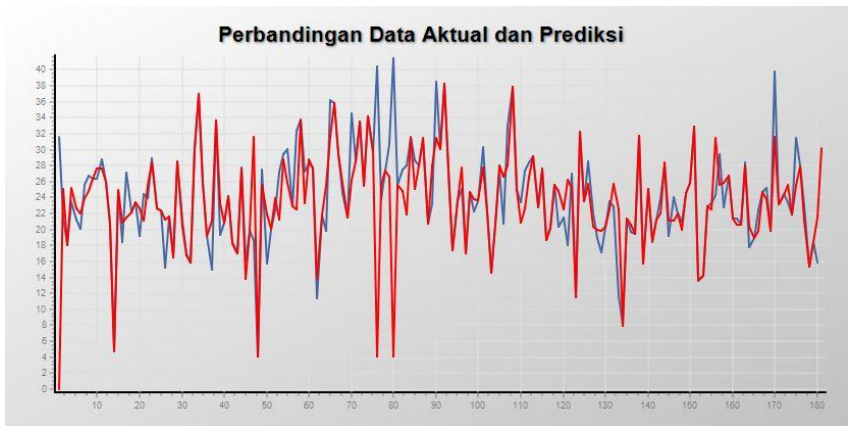

Gambar 5. Struktur Antarmuka Aplikasi 


\subsection{Analisis Hasil Uji}

Berdasarkan hasil pengujian yang telah dilakukan dengan berbagai jenis data, periode, dan jumlah interval, maka rangkuman hasil pengujian dapat dilihat pada Tabel VI.

TABEL VI

TABEL HASIL PENGUJIAN APLIKASI

\begin{tabular}{|c|c|c|}
\hline Jumlah Tahun & Periode & Nilai MAPE (\%) \\
\hline 1 & 2017 & 7.1007 \\
\hline 2 & $2016-2017$ & 3.6946 \\
\hline 3 & $2015-2017$ & 0.1509 \\
\hline 4 & $2014-2017$ & 0.6460 \\
\hline 5 & $2013-2017$ & 3.1105 \\
\hline 6 & $2012-2017$ & 2.7348 \\
\hline 7 & $2011-2017$ & 4.3438 \\
\hline 8 & $2010-2017$ & 3.8931 \\
\hline 9 & $2009-2017$ & 5.5051 \\
\hline 10 & $2008-2017$ & 5.6795 \\
\hline 11 & $2007-2017$ & 5.9691 \\
\hline 12 & $2006-2017$ & 7.3314 \\
\hline 13 & $2005-2017$ & 7.5127 \\
\hline 14 & $2004-2017$ & 7.6237 \\
\hline 15 & $2003-2017$ & 7.6522 \\
\hline
\end{tabular}

Maka berdasarkan hasil pengujian yang ditampilkan dalam Tabel VI, analisis hasil pengujian aplikasi adalah sebagai berikut :

1. Banyaknya jumlah data yang digunakan memberikan pengaruh besar pada hasil peramalan. Data tersebut digunakan oleh sistem untuk menghitung, menganalisis, dan menentukan pola data yang kemudian akan digunakan untuk memproyeksikan peramalan.

2. Jumlah interval yang digunakan dalam membagi data untuk perhitungan juga memberikan pengaruh pada hasil peramalan. Berdasarkan hasil pengujian pada sistem, ditemukan bahwa nilai interval terbaik yang dapat digunakan untuk membagi data sehingga menghasilkan nilai $M A P E$ yang baik adalah interval 401.

3. Pada peramalan dengan menggunakan data curah hujan, nilai $M A P E$ yang paling baik dihasilkan adalah $0,151 \%$ pada periode 2015 - 2017 dengan menggunakan jumlah interval 401. Dengan demikian pada peramalan tersebut memiliki nilai akurasi sejumlah 99,849\%.

4. Metode Fuzzy Time Series memiliki nilai akurasi lebih tinggi pada saat digunakan untuk melakukan peramalan pada data yang memiliki pola musiman daripada data yang memiliki pola abstrak.

\section{KESIMPULAN}

Berdasarkan hasil uji dan analisis hasil uji, maka dapat disimpulkan bahwa :

1. Aplikasi yang dibangun dapat melakukan proses olah data curah harian menjadi data curah hujan bulanan serta melakukan proses perhitungan prediksi curah hujan dengan metode Fuzzy Time Series.

2. Penggunaan metode Fuzzy Time Series dalam aplikasi memungkinkan sistem untuk menentukan pola data time series yang digunakan kemudian memproyeksikan pola data tersebut untuk memperoleh hasil prediksi.

3. Hasil perhitungan prediksi Fuzzy Time Series sangat dipengaruhi oleh jumlah data aktual yang digunakan sebagai acuan perhitungan pola data serta jumlah interval pada saat perhitungan pola data.

\section{DAFTAR PUSTAKA}

[1] Huang, K. 2001. Heuristic Models of Fuzzy Time Series for Forecasting. Journal of Fuzzy Sets and Systems

[2] Synaptic. 2005. Fuzzy Math, Part I, The Theory. http://www.scholarpedia.org/article/Fuzzy_logic.

[3] Daldjoeni, N. 1986. Pokok-pokok Klimatologi. Bandung : Alumni.

[4] Mandey, F. N. 2017. Pemodelan Sistem Prediksi Intensitas Curah Hujan Kota Manado dengan Menggunakan Kontrol Logika Fuzzy. Jurnal MIPA UNSRAT.

[5] Buffa, E.S. \& Sarin, R.K. 2007. Modern Production / Operation Management, $8^{\text {th }}$ Ed. United States : John Wiley and Sons, Inc.

[6] Brata, A. S. 2016. Penerapan Fuzzy Time Series dalam Peramalan Data Seasonal. Malang : Universitas Islam Negeri Maulana Malik Ibrahim.

[7] Hisyam, M., Lee \& Suharto. 2012. A Weighted Fuzzy Time Series Model for Forecasting Seasonal Data.

[8] Saleh, M. N. 2017. Implementasi Peramalan Menggunakan Fuzzy Time Series pada Aplikasi Helpdesk Inventaris Perangkat Teknologi Informasi. Jurnal Sistem dan Teknologi Informasi (JUSTIN) Vol.1, No. 2

[9] Makridakis, S., Steven, C., Wheelwright, V.E., \& McGee. 1999. Metode dan Aplikasi Peramalan Jilid 2. Jakarta : Binarupa Aksara.

[10] Soewarno. 2015. Klimatologi, Pengukuran dan Pengolahan Data Curah Hujan, Contoh Aplikasi Hidrologi dalam Pengelolaan Sumber Daya Air. Yogyakarta : Graha Ilmu.

[11] Triadmojo, Bambang. 2008. Hidrologi Terapan. Yogyakarta : Beta Offset.

[12] Heizer, J. \& Render, B. 2005. Operation Management, $7^{\text {th }}$ Edition. Jakarta : Penerbit Salemba Empat.

[13] Halimi, Imam. 2018. Prediksi Indeks Harga Saham Gabungan (IHSG) Menggunakan Algoritma Neural Network. Jurnal Edukasi dan Penelitian Informatika (JEPIN) Vol.4, No.1.

[14] Hwang, J.R., Chen, S.M \& Lee, C.H. Handling Forecasting Problems using Fuzzy Time Series. Journal of Fuzzy Sets and Systems.

[15] Kusumadewi, S. \& Purnomo, H. 2004. Aplikasi Logika Fuzzy untuk Pendukung Keputusan. Yogyakarta : Graha Ilmu.

[16] Kusumadewi, S. 2002. Analisis Desain Fuzzy Menggunakan Tool Box Matlab. Yogjakarta : Graha Ilmu.

[17] Nikentari, N. 2018. Prediksi Kecepatan Angin Menggunakan Adaptive Neuro Fuzzy (ANFIS) dan Radical Basis Function Neural Network (RBFNN). Jurnal Edukasi dan Penelitian Informatika (JEPIN) Vol.4, No.1.

[18] Chen, S.M. 1996. Forecasting Enrollments Based on Fuzzy Time Series. Journal of Fuzzy Sets and Systems.

[19] Elfajar, A. B. 2017. Peramalan Jumlah Kunjungan Wisatawan Kota Batu Menggunakan Metode Time Invariant Fuzzy Time Series. Jurnal Pengembangan Teknologi Informasi dan Ilmu Komputer Vol.1, No.2.

[20] Pakaja, F., Naba, A., Purwanto. (2012), Peramalan Penjualan Mobil Menggunakan Jaringan Syaraf Tiruan dan Certainty Factor, Jurnal EECCIS, Vol.6, No.1, Juni 2012. 